\title{
PEMETAAN PEMBELAJARAN BIOLOGI BERBASIS SCIENTIFIC APPROACH DI SMA NEGERI 1 BINJAI
}

\author{
Ummu Rahmatika*, Amrizal \\ Program Studi Pendidikan Biologi,FMIPA Universitas Negeri Medan,Medan \\ Jl. Williem Iskandar Psr. V Medan Estate, Medan, Indonesia,20221 \\ *Email: rahmatikaummu@gmail.com
}

\begin{abstract}
ABSTRAK
Penelitian ini bertujuan untuk mengetahui pelaksanaan pembelajaran biologi berbasis scientific approach, kegiatan belajar berdasarkan pembelajaran saintifik, aktivitas yang dominan dalam penerapan scientific approach, dan tahapan belajar saintifik yang merupakan masalah dalam pembelajaran biologi di SMA Negeri 1 Binjai T.P.2016/2017. Desain penelitian yang digunakan yaitu deskriptif kuantitatif dengan menggunakan metode survei. Sampel yang diambil berjumlah 2 orang guru biologi dan 114 orang siswa. Teknik pengumpulan data dengan menggunakan, lembar observasi, angket siswa, dan pedoman wawancara. Hasil analisis menunjukkan bahwa pelaksanaan pembelajaran dengan pandekatan saintifik adalah sebesar $80 \%$ dengan interpretasi terlaksana cukup. Sementara aktivitas tahapan belajar mengamati, menanya, mencoba, mengasosiasi, dan mengomunikasikan adalah sebesar $86 \%, 85 \%, 75 \%, 78 \%, 75 \%$ dengan rata-rata terlaksana cukup. Tahapan belajar saintifik yang dominan yaitu mengamati, dan tahapan belajar saintifik yang merupakan masalah dalam pembelajaran yaitu menanya, dan mengumpulkan informasi.
\end{abstract}

Kata Kunci: kegiatan pembelajaran pendekatan saintifik, pelaksanaan pembelajaran, aktivitas pembelajaran.

ABSTRACT
This study aims to determine the implementation of biological learning based on scientific approach, learning activities based on scientific learning, the dominant activity in the application of scientific approach, and scientific learning stages which is a problem in biology learning in SMA Negeri 1 Binjai T.P.2016 / 2017. The research design used is descriptive quantitative by using survey method. The samples were 2 biology teachers and 114 students. Data collection techniques using, observation sheets, student questionnaires, and interview guidelines. The result of the analysis shows that the implementation of learning with scientific approach is $80 \%$ with the interpretation implemented sufficiently. While the learning phase activity observes, asks, tries, associates, and communicates it is $86 \%, 85 \%, 75 \%, 78 \%, 75 \%$ with average enough to do. The dominant scientific learning stage is observation, and the scientific learning stage which is a problem in learning that is asking, and collecting information.

Keywords: learning activities of scientific approach, implementation of learning, learning activity.

\section{PENDAHULUAN}

Kurikulum di Indonesia sekarang ini menggunakan 2 macam Kurikulum yaitu Kurikulum 2006 (KTSP) dan Kurikulum 2013, berdasarkan Peraturan Menteri Pendidikan dan Kebudayaan Republik Indonesia Nomor 160 tahun 2014 tentang pemberlakuan Kurikulum tahun 2006 (KTSP) dan Kurikulum 2013.

Kurikulum 2013 dalam pelaksanaan pembelajaran menerapkan pendekatan saintifik (scientific approach). Langkah 5M pada pendekatan saintifik merupakan pengembangan dari 3 langkah kegiatan inti pembelajaran pada Kurikulum Tingkat Satuan Pendidikan (KTSP), yakni 1) eksplorasi kegiatan mengamati dan menanya; 2) elaborasi kegiatan mengumpulkan informasi/mencoba dan mengasosiasi; 3) konfirmasi kegiatan mengomunikasikan. Sehingga, seharusnya tidak terdapat kendala khusus dalam penerapan kurikulum 2013 di setiap sekolah.

Pembelajaran pada Kurikulum 2013 tidak jauh berbeda dengan Kurikulum sebelumnya (KBK/KTSP). Karena pada dasarnya Kurikulum 2013 merupakan pengembangan dari Kurikulum lama tersebut, hanya saja pembelajaran pada Kurikulum 2013 ini lebih menggunakan pendekatan saintifik. Proses pembelajaran pada satuan pendidikan diselenggarakan secara interaktif, inspiratif, menyenangkan, menantang, memotivasi peserta didik untuk berpartisipasi aktif serta memberikan ruang yang cukup bagi prakarsa, kreativitas, dan kemandirian sesuai dengan bakat, minat, dan 
perkembangan fisik serta psikologis peserta didik. Untuk itu setiap satuan pendidikan melakukan perencanaan pembelajaran, pelaksanaan pembelajaran serta penilaian proses pembelajaran untuk meningkatkan efisiensi dan efektivitas ketercapaian kompetensi lulusan (Fadlillah, 2014).

Scientific approach ialah pendekatan yang digunakan dalam pembelajaran dan dilakukan melalui proses ilmiah. Apa yang dipelajari dan diperoleh peserta dilakukan dengan indra dan akal pikiran sendiri sehingga mereka mengalami secara langsung dalam proses mendapatkan ilmu pengetahuan (Fadlillah, 2014). Pendekatan saintifik (scientific approach) dalam pembelajaran yang memiliki komponen proses pembelajaran antara lain: mengamati (observing), menanya (questioning), mencoba (experimenting), menalar (associating), mengkomunikasikan (communicating) (Sani, 2014).

Sasaran pembelajaran dengan pendekatan ilmiah mencakup pengembangan ranah sikap, pengetahuan, dan keterampilan yang dielaborasi untuk setiap satuan pendidikan. Ketiga ranah kompetensi tersebut memiliki lintasan perolehan (proses) psikologis yang berbeda. Sikap diperoleh melalui aktivitas: menerima, menjalankan, menghargai, menghayati, dan mengamalkan. Pengetahuan diperoleh melalui aktivitas: mengingat, memahami, menerapkan, menganalisis, mengevaluasi, dan mencipta. Sementara itu, keterampilan diperoleh melalui aktivitas: mengamati, menanya, menalar, menyaji, dan mencipta (Rahmatiah, 2015). Menurut Mc. Collum dalam Rahmatiah, (2015) komponenkomponen penting dalam mengajar menggunakan pendekatan saintifik diantaranya adalah guru harus menyajikan pembelajaran yang dapat meningkatkan rasa keingintahuan (Foster a sense of wonder), meningkatkan keterampilan mengamati (Encourage observation), melakukan analisis (Push for analysis) dan berkomunikasi (Require communication).

Pendekatan saintifik menawarkan terobosan yang signifikan dalam meningkatkan kualitas pembelajaran dengan pendekatan saintifik pembelajaran lebih efektif dapat membuat siswa terlibat aktif dalam kegiatan di kelas terutama dapat melatih kemampuan siswa dalam keterampilan berbicara, mendengarkan, membaca, dan menulis (Zaim, 2017). Menurut Hidayah dalam Said, dkk. (2016) pembelajaran dengan pendekatan saintifik, siswa berperan secara langsung dalam kegiatan pembelajaran baik secara individu maupun kelompok untuk mengeksplorasi konsep dan prinsip-prinsip selama kegiatan belajar dan tugas guru yaitu untuk memberikan arahan dan masukan mengenai konsep dan prinsip-prinsip yang telah diperoleh siswa selama proses pembelajaran.

Kegiatan pembelajaran pendekatan saintifik (5M) di dalam pembelajaran tidak hanya mendorong partisipasi aktif peserta didik di dalam kelas, tetapi juga memberikan ruang yang cukup bagi prakarsa, kreativitas, dan kemandirian sesuai dengan bakat, minat, dan perkembangan fisik serta psikologis peserta didik (Wardani, 2014). Menurut Hosnan dalam Selvira, (2016) pendekatan saintifik dimaksudkan untuk memberikan pemahaman kepada peserta didik dalam mengenal dan memahami berbagai materi menggunakan pendekatan ilmiah, bahwa informasi bisa berasal dari mana saja, kapan saja dan tidak bergantung pada informasi searah dari guru. Penerapan pendekatan saintifik dalam pembelajaran melibatkan keterampilan proses seperti mengamati, menanya, mencoba, menalar, dan mengkomunikasikan. Dalam melaksanakan proses tersebut dibutuhkan bantuan guru.

Dalam pendekatan saintifik masalah yang diberikan guru selalu berdasarkan dengan fenomena yang selama ini terjadi di kehidupan para siswa, lalu siswa mencoba mencari jawaban dari masalah yang diberikan secara mandiri sehingga siswa tidak hanya mengetahui fakta atau prinsip, tetapi harus terampil menerapkan pengetahuannya dalam kehidupan. Penggunaan pendekaan saintifik dimaksudkan agar proses pembelajaran menjadi lebih baik. Namun, jika pendekatan saintifik digunakan semata-mata karena tuntutan Kurikulum 2013, maka akan kehilangan esensi pendekatan saintifik dan dalam praktiknya guru sulit untuk menerapkan dalam pembelajaran di kelas (Budiyanto, 2016). Hasil penelitian Mustofa, (2015) mengatakan bahwa pemahaman guru tentang kurikulum 2013 khususnya dalam pembelajaran dengan pendekatan saintifik belum memadai, guru masih menerapkan pembelajaran konseptual dan belum 
optimal dalam menerapkan pendekatan saintifik serta guru masih memerlukan penyamaan persepsi tentang pembelajaran saintifik.

Berdasarkan uraian di atas, perlu dikaji lebih lanjut mengenai pemetaan pembelajaran biologi berbasis pendekatan saintifik (scientific approach). Tujuan penelitian adalah untuk mengetahui pelaksanaan pembelajaran berbasis scientific approach yang dilakukan selama pembelajaran biologi, kegiatan belajar berdasarkan pembelajaran saintifik (scientific approach), aktivitas dari tahapan belajar saintifik yang dominan dilakukan selama pembelajaran biologi, tahapan belajar dari pendekatan saintifik yang merupakan masalah dalam pembelajaran biologi.

\section{METODE PENELITIAN}

Penelitian ini merupakan penelitian Kuantitatif dengan jenis penelitian deskriptif dengan menggunakan metode survei yaitu mengumpulkan data sebanyak-banyaknya yang mendeskripsikan/menggambarkan suatu gejala, pristiwa berdasarkan fakta nyata. Sampel penelitian ini adalah guru biologi yang telah menerapkan Kurikulum 2013 dalam pembelajaran sebanyak 2 orang, dan siswa sebanyak 114 orang. Penelitian dilaksanakan pada bulan Maret - Juni 2017 dengan menggunakan teknik observasi, angket, dan wawancara. Data observasi pembelajaran saintifik dianalisis secara deskriptif dengan metode persentase, sementara data angket pelaksanaan pembelajaran dianalisis menggunakan metode skoring, dan data wawancara pemahaman guru tentang scientific approach dianalisis secara deskriptif.

\section{HASIL PENELITIAN}

Berdasarkan hasil penelitian pelaksanaan pembelajaran di kelas X SMA Negeri 1 Binjai, Tahap pembelajaran Kurikulum 2013 terdiri atas tiga tahap yaitu, kegiatan pendahuluan, kegiatan inti, dan kegiatan penutup. Kurikulum 2013 menggunakan pendekatan saintifik yang diterapkan dalam kegiatan inti pembelajaran melalui mengamati, menanya, mengumpulkan informasi, mengasosiasi, dan mengomunikasikan. Berikut adalah hasil tahapan pembelajaran saintifik (scientific approach) yang telah dilakukan dalam pembelajaran biologi.

Tabel 1. Tahapan Pelaksanaan Pembelajaran Saintifik

\begin{tabular}{llcccc}
\hline \multirow{2}{*}{ No } & \multirow{2}{*}{ Tahapan Pembelajaran } & \multicolumn{2}{c}{$\begin{array}{c}\text { Rata-Rata } \\
\text { Terlaksana }\end{array}$} & \multicolumn{2}{c}{ Rata-Rata Keseluruhan } \\
\cline { 3 - 6 } & & $\mathbf{0}$ & $\mathbf{A}$ & Nilai (\%) & Interpretasi \\
\hline 1. & Pendahuluan pembelajaran & 76 & 80 & 78 & Cukup \\
\hline 2. & Mengamati & 86 & 86 & 86 & Baik \\
\hline 3. & Menanya & 85 & 84 & 84,5 & Baik \\
\hline 4. & Mencoba/mengumpulkan informasi & 75 & 75,7 & 75,3 & Cukup \\
\hline 5. & Mengasosiasi/menalar & 78 & 78,5 & 78,2 & Cukup \\
\hline 6. & Mengomunikasikan & 75 & 76 & 75,5 & Cukup \\
\hline 7. & Penutup pembelajaran & 80 & 84,4 & 82,2 & Baik \\
\hline & & & & 80 & Cukup \\
\hline
\end{tabular}

Keterangan Tabel: $\mathrm{O}=$ observasi, $\mathrm{A}=$ angket

Berdasarkan pada Tabel 1. diketahui bahwa pendahuluan pembelajaran sebesar $78 \%$, mengamati sebesar $86 \%$, menanya sebesar $84,5 \%$, mencoba/mengumpulkan informasi sebesar 75,3\%, mengasosiasi/menalar sebesar 78,2\%, mengomunikasikan sebesar $75,5 \%$, dan penutup pembelajaran sebesar $82,2 \%$.
Berdasarkan Tabel 1. dapat disimpulkan bahwa pembelajaran biologi di SMA Negeri 1 Binjai dengan pendekatan saintifik terlaksana cukup baik. Oleh karena itu, dapat dideskripsikan kegiatan belajar berdasarkan pembelajaran saintifik dari tahapan belajar mengamati, menanya, mencoba, mengasosiasi, dan mengomunikasikan yang dapat dilihat pada Tabel 2 . berikut. 
Halaman : $028-035$

Tabel 2. Kegiatan Belajar Berdasarkan Pembelajaran Saintifik di Kelas X SMA Negeri 1 Binjai

\begin{tabular}{|c|c|}
\hline $\begin{array}{c}\text { Tahapan Belajar } \\
\text { Saintifik }\end{array}$ & Kegiatan Yang Dilakukan \\
\hline Mengamati & $\begin{array}{l}\text { Siswa membaca dari buku/internet (ekosistem, pelestarian lingkungan), melihat gambar } \\
\text { (contoh ekosistem, rantai makanan, dan daur biogekimia) serta vidio (daur Karbon), } \\
\text { mendengarkan penjelasan guru }\end{array}$ \\
\hline Menanya & $\begin{array}{l}\text { Guru menstimulus siswa untuk bertanya dengan cara guru mengajukan beberapa pertanyaan } \\
\text { untuk memotivasi siswa bertanya, memberikan kejelasan kepada siswa tentang materi } \\
\text { pertanyaan yang harus diajukan, setiap siswa diminta untuk menyiapkan pertanyaan yang } \\
\text { harus diajukan. Pada kegiatan ini siswa terlihat malu-malu atau kurangnya percaya diri dari } \\
\text { siswa untuk mengajukan pertanyaan, pada tiap kelas umumnya lima sampai tujuh orang yang } \\
\text { berani mengajukan pertanyaan. Siswa lebih antusias dalam menjawab pertanyaan } \\
\text { dibandingkan untuk mengajukan pertanyaan, tetapi jika diperiksa setiap siswa telah } \\
\text { menyimpan pertanyaannya masing-masing. Hanya saja kurangnya rasa keberanian untuk } \\
\text { mengajukan pertanyaan. }\end{array}$ \\
\hline $\begin{array}{l}\text { Mencoba/ me- } \\
\text { ngumpulkan } \\
\text { informasi }\end{array}$ & $\begin{array}{l}\text { Siswa membaca dari buku/internet (ekosistem, faktor yang mempengaruhi ekosistem, tahapan } \\
\text { suksesi primer dan skunder), mengamati serta mengumpulkan informasi (berbagai usaha yang } \\
\text { dapat dilakukan untuk menangani masalah limbah, apa saja produk daur ulang limbah yang } \\
\text { dapat dibuat/dilakukan), mengumpulkan informasi dengan cara mendengarkan penjelasan } \\
\text { guru, presentasi kelompok siswa. Pada kegiatan ini tidak ada pemberian lembar kegiatan siswa } \\
\text { (LKS) yang berisi mengenai beberapa tugas yang harus dikerjakan siswa. }\end{array}$ \\
\hline $\begin{array}{l}\text { Menalar/ } \\
\text { mengasosiasi }\end{array}$ & $\begin{array}{l}\text { Siswa menyimpulkan dari hasil pengamatan yang telah dilakukan siswa pada kegiatan } \\
\text { pengamatan, dan pada kegiatan mengumpulkan informasi. Siswa mengambil poin-poin } \\
\text { penting dari hasil presentasi kelompok, membaca buku/internet, dan dari hasil penjelasan } \\
\text { guru, serta siswa mengerjakan beberapa tugas yang telah diberikan guru dalam bentuk tugas } \\
\text { tertulis siswa. }\end{array}$ \\
\hline $\begin{array}{l}\text { Mengomunikasi } \\
\text { kan }\end{array}$ & $\begin{array}{l}\text { Guru memfasilitasi siswa untuk melakukan kegiatan mengomunikasikan dengan meminta } \\
\text { siswa untuk membuat laporan tertulis sederhana, dan juga meminta siswa untuk } \\
\text { mempresentasikan hasil mereka dengan cara lisan ataupun tertulis. }\end{array}$ \\
\hline
\end{tabular}

Berdasarkan hasil analisis aktivitas pembelajaran dari tahapan belajar saintifik yang dilakukan selama pembelajaran biologi dapat dilihat pada Gambar 1.

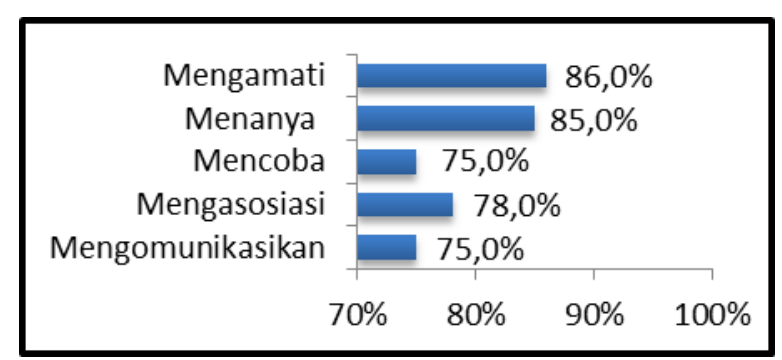

Gambar 1. Penerapan Pendekatan Saintifik

Dari Gambar 1. diketahui bahwa aktivitas mengamati sebesar $86 \%$, menanya sebesar $85 \%$, menalar/mengasosiasi sebesar 78\%, dan mencoba/mengumpulkan informasi serta mengomunikasikan sebesar $75 \%$. Tahapan belajar pendekatan saintifik yang dominan dilakukan dalam pembelajaran biologi yaitu tahapan belajar mengamati sebesar $86 \%$ (terlaksana baik). Berdasarkan hasil kegiatan belajar saintifik yang merupakan masalah dalam pembelajaran dapat 
dilihat pada Tabel 3. Berdasarkan uraian pada Tabel 3. dapat dilihat bahwa bahwa tahapan belajar saintifik yang merupakan masalah dalam pembelajaran yaitu kegiatan menanya, dan mengumpulkan informasi.

Tabel 3. Tahapan Belajar Saintifik yang merupakan masalah dalam pembelajaran biologi

\begin{tabular}{ll}
\hline No. & \multicolumn{1}{c}{ Masalah Yang Muncul Dalam Pembelajaran } \\
\hline 1. & Guru menstimulus siswa bertanya dengan memberikan pertanyaan kepada siswa. \\
2. & Siswa kurang percaya diri dalam mengajukan pertanyaan dan tidak semua siswa aktif bertanya, pada \\
& tiap kelas umumnya lima sampai tujuh siswa. \\
3. & Siswa lebih terlibat aktif dalam menjawab pertanyaan daripada siswa yang bertanya. \\
4. & Siswa mengumpulkan data dari buku siswa/internet, serta penjelasan dari guru. \\
5. & Guru tidak ada memberikan lembar kegiatan siswa (LKS) dikarenakan lembar kegiatan siswa tidak \\
& disediakan, dan tidak terdapat pada RPP.
\end{tabular}

\section{PEMBAHASAN}

Kegiatan pendahuluan merupakan kegiatan awal dalam proses pembelajaran yang harus dilakukan untuk menciptakan suasana belajar yang efektif. Kegiatan yang cenderung dilaksanakan guru yaitu menyiapkan fisik dan psikis siswa dan mengaitkan materi dengan materi pembelajaran sebelumnya agar siswa lebih siap dalam belajar, sesuai dengan pendapat Sanjaya, (2011) membuka pelajaran adalah suatu usaha yang dilakukan guru dalam kegiatan pembelajaran untuk menciptakan prakondisi bagi siswa agar mental maupun perhatian terpusat pada hal-hal yang akan dipelajari sehingga akan mudah mencapai kompetensi yang diharapkan (Sanjaya, 2011). Adapun kegiatan yang kurang terlaksana yaitu kegiatan mendemonstrasikan, kegiatan menyampaikan manfaat materi pembelajaran, dan guru tidak selalu menyampaikan kemampuan yang akan dicapai siswa. Tidak terlaksananya kegiatan disebabkan karena penyampaian manfaat materi atau kemampuan yang akan dicapai siswa hanya disampaikan guru pada materi baru diawal pembelajaran untuk pertemuan selanjutnya cenderung tidak disampaikan. Menurut Sanjaya, (2011) memperjelas pemahaman siswa tentang tujuan pembelajaran dapat menumbuhkan minat siswa untuk belajar yang pada gilirannya dapat meningkatkan motivasi belajar siswa.

Kegiatan inti yang telah dilakukan dengan menggunakan pendekatan saintifik dengan tahapan mengamati, menanya, mengumpulkan data, mengasosiasi, dan mengkomunikasikan.
Kegiatan inti yang dilakuakan guru memang tidak menggunakan lingkungan nyata sebagai objek pembelajaran, tetapi guru menggunakan mediamedia pembelajaran untuk menutup kekurangan tersebut. Gambar-gambar dan video yang ditampilkan guru merupakan gambar yang ada di sekitar kita, sehingga walau hanya terbatas pengetahuan visual 2 dimensi siswa tetap bisa memanfaatkan dan mengolah informasi tersebut dengan mudah.

Tahapan belajar mengamati meliputi, meminta siswa membaca dari buku atau dari internet, melihat gambar (contoh ekosistem, rantai makanan, dan daur biogekimia), serta video (daur Karbon), siswa mendengarkan penjelasan dari guru. Hal ini sesuai dengan Permendikbud RI Nomor 81A Tahun 2013 bahwa Kegiatan belajar yang dilakukan dalam proses mengamati adalah membaca, mendengar, menyimak, melihat (tanpa atau dengan alat). Kompetensi yang dikembangkan adalah melatih kesungguhan, ketelitian, dan mencari informasi.

Tahapan belajar menanya meliputi, mengajukan pertanyaan kepada siswa, memberikan kejelasan materi yang harus diajukan siswa, meminta siswa menyiapkan pertanyaan. Oleh sebab itu, siswa terlihat malu-malu atau kurangnya percaya diri dari siswa untuk mengajukan pertanyaan, pada tiap kelas umumnya siswa yang bertanya lima sampai tujuh orang. Siswa lebih antusias dalam menjawab pertanyaan daripada mengajukan pertanyaan. Sebab guru tidak memfasilitasi, menunjukkan/ 
memperlihatkan ataupun mendemonstrasikan sesuatu yang dapat menyebabkan siswa tertarik untuk bertanya sendiri. Kegiatan menanya, guru harus dapat menciptakan media/sumber belajar yang menarik agar siswa ingin dan merasa tertarik terhadap objek belajar, sehingga siswa dapat mengungkapkan pertanyaannya secara mandiri. Menurut Permendikbud Nomor 81A Tahun 2013 tentang Implementasi Kurikulum, bahwa kegiatan $5 \mathrm{M}$ dalam pendekatan saintifik adalah kegiatan yang dilakukan oleh siswa. Oleh karena itu, kegiatan menanya memposisikan siswa sebagai subyek yang mengajukan pertanyaan.

Tahapan belajar mencoba/mengumpulkan informasi meliputi, siswa membaca dari buku dan dari internet, mengamati (ekosistem, faktor yang mempengaruhi ekosistem, tahapan suksesi primer dan skunder), mendengarkan penjelasan dari guru, dan menyimak presentasi kelompok siswa. Kegiatan mengumpulkan informasi juga dilakukan siswa dalam rangka menjawab pertanyaan. Menurut Permendikbud Nomor 81A Tahun 2013 yang menyatakan bahwa pada kegiatan mengumpulkan data siswa dapat melaksanakan penyelidikan, eksperimen, membaca sumber lain seperti buku teks, media cetak, mengamati objek atau kejadian, aktivitas, dan wawancara dengan nara sumber untuk dapat memperoleh sejumlah informasi.

Tahapan belajar menalar/mengasosiasi meliputi, siswa menyimpulkan dari hasil pengamatan, guru meminta siswa untuk dapat mengambil poin-poin penting dari hasil presentasi kelompok, membaca buku/internet, dan dari hasil penjelasan guru, siswa mengerjakan tugas yang telah diberikan guru dalam bentuk tugas tertulis siswa, sehingga siswa harus dapat menjawab, mengklasifikasikan, ataupun menyimpulkan dari hasil siswa membaca, mengamati, menyimak untuk menjawab pertanyaan umpan/tugas yang telah diberikan guru. Hal ini sesuai dengan Permendikbud Nomor 81A Tahun 2013 yang menyatakan bahwa kegiatan mengolah informasi yang telah dikumpulkan baik dari hasil kegiatan mengumpulkan/eksperimen maupun hasil dari kegiatan mengamati, kegiatan mengumpulkan informasi, pengolahan informasi yang dikumpulkan bersifat menambah keluasaan dan kedalaman sampai kepada pengolahan informasi yang bersifat mencari solusi dari berbagai sumber.

Tahapan belajar mengomunikasikasn meliputi, meminta siswa untuk membuat laporan tertulis sederhana, dan juga meminta siswa untuk mempresentasikan hasil mereka dengan cara lisan ataupun tertulis. Hal ini sesuai dengan Permendikbud Nomor 81A Tahun 2013 yang menyatakan bahwa kegiatan mengomunikasikan dapat dilakukan dengan menyampaikan hasil pengamatan, kesimpulan berdasarkan hasil analisis secara lisan, tertulis atau media lainnya.

Dalam kegiatan pembelajaran guru tidak menggunakan sumber belajar yang bervariasi, sumber belajar yang digunakan yaitu buku teks biologi kelas $\mathrm{X}$, dan media yang digunakan yaitu gambar/vidio pembelajaran melalui tayangan slide. Menurut Sanjaya, (2011) kemampuan memanfaatkan berbagai sumber belajar/media merupakan salah satu kompetensi yang harus dimiliki oleh seorang guru profesional, dengan perancangan media yang dianggap cocok akan memudahkan proses pembelajaran, sehingga pada gilirannya tujuan pembelajaran akan tercapai secara optimal.

Kegiatan akhir dalam pembelajaran tidak hanya diartikan sebagai kegiatan untuk menutup pelajaran, tetapi juga sebagai kegiatan penilaian hasil belajar siswa dan kegiatan tindak lanjut. Pada kegiatan penutup pembelajaran guru kurang membimbing siswa untuk merefleksi pembelajaran yang telah dipelajari ataupun membimbing siswa untuk menyimpulkan pembelajaran, pada kegiatan ini guru cenderung memberikan tes lisan ataupun tulisan serta melaksanakan tindak lanjut dengan memberikan arahan kegiatan berikutnya dan tugas pengayaan kepada siswa untuk melihat tingkat keberhasilan siswa. Menurut Sanjaya, (2011) menutup pelajaran dapat diartikan sebagai kegiatan yang dilakukan guru untuk mengakhiri pelajaran dengan maksud untuk memberikan gambaran menyeluruh tentang apa yang telah dipelajari siswa serta keterkaitannya dengan pengalaman sebelumnya, mengetahui tingkat keberhasilan siswa, serta keberhasilan guru dalam proses pembelajaran.

Adapun tahapan belajar saintifik yang merupakan masalah dalam pembelajaran yaitu menanya, dan mengumpulkan informasi. Kegiatan 
menanya, guru harus dapat menciptakan media/sumber belajar yang menarik agar siswa ingin dan merasa tertarik terhadap objek belajar, sehingga siswa dapat mengungkapkan pertanyaannya secara mandiri.

Terdapat beberapa kegiatan dalam tahapan mengumpulkan informasi yang kurang dilaksanakan yaitu pemberian lembar kegiatan siswa untuk kegiatan pengamatan lapangan, dan guru tidak menyediakan referensi bagi siswa dalam rangka menjawab pertanyaan, Kegiatan mengumpulkan data dilakukan siswa dari buku/internet, serta dari penjelasan guru. Kegiatan mengumpulkan data dapat juga dilaksanakan dengan mengamati lingkungan sekolah, diskusi, studi literatur, percobaan atau eksperimen, serta mengamati gambar/charta.

\section{KESIMPULAN}

Hasil analisis pelaksanaan pembelajaran dengan pandekatan saintifik adalah sebesar $80 \%$ dengan interpretasi cukup terlaksana. Sementara aktivitas tahapan belajar mengamati, menanya, mencoba, mengasosiasi, dan mengomunikasikan adalah sebesar 86\%, 85\%, 75\%, 78\%, 75\%. Tahapan belajar saintifik yang dominan yaitu mengamati sebesar $86 \%$ (terlaksana baik). Adapun tahapan belajar saintifik yang merupakan masalah dalam pembelajaran yaitu menanya, dan mengumpulkan informasi.

\section{DAFTAR PUSTAKA}

Amri, S., (2016), Pengembangan dan Model Pembelajaran dalam Kurikulum 2013, Prestasi Puspakarya, Jakarta.

Arikunto, S., (2006), Prosedur Penelitian Suatu Pendekatan Praktek, Rineka Cipta, Jakarta.

Budiyanto, M.A.K., Waluyo, L., dan Mokhtar, A., (2016), Implementasi Pendekatan Saintifik dalam Pembelajaran di Pendidikan Dasar di Malang, Proceeding Biology Education Conference, 1: 46-51.

Fadlillah, M., (2014), Implementasi Kurikulum 2013, Ar-Ruzz Media, Yogyakarta.

Irnaningtyas, (2016), Biologi Untuk SMA/MA Kelas X Kurikulum 2013, Erlangga, Jakarta.
Kemendikbud, (2013), Peraturan Menteri Pendidikan dan Kebudayaan Republik Indonesia Nomor 81A Tahun 2013 Tentang Implementasi Kurikulum, Kemendikbud, Jakarta.

Kemendikbud, (2014), Modul Pelatihan Implementasi Kurikulum 2013, Badan Pengembangan Sumber Daya Manusia Pendidikan dan Kebudayaan dan Penjaminan Mutu Pendidikan, Jakarta.

Kemendikbud, (2014), Peraturan Menteri Pendidikan dan Kebudayaan Republik Indonesia Nomor 160 Tahun 2014 Tentang Pemberlakuan Kurikulum Tahun 2006 dan Kurikulum 2013, Kemendikbud, Jakarta.

Kemendikbud, (2016), Peraturan Menteri Pendidikan dan Kebudayaan Republik Indonesia Nomor 22 Tahun 2016 Tentang Standar Proses Pendidikan Dasar dan Menengah, Kemendikbud, Jakarta.

Mustofa, (2015), Pemetaan Kesiapan Implementasi Pendekatanan Saintifik di SMP, Jurnal Pendidikan Geografi, 20: 61-67.

Rahmatiah, (2015), Pendekatan Saintifik Sebagai Solusi Dalam Pembelajaran Biologi, Buletin Media LPMP Sulsel, ISSN. 23553189.

Rohani, A., (2004), Pengelolaan Pengajaran, Rineka Cipta, Jakarta.

Said, I.M., Sutadji, E., dan Sugandi, M., (2016), The Scientific Approach Based Cooperative Learning Tool for Vocational Students Vocation Program of Autotronic (Automotive Electronic) Engineering, IOSR Journal of Research \& Method in Education, 6: 67-73.

Sani, R.A., (2014), Pembelajaran Saintifik Untuk Kurikulum 2013, Bumi Aksara, Jakarta.

Sani, R.A., (2016), Penilaian Autentik, Bumi Aksara, Jakarta.

Sanjaya, W., (2011), Strategi Pembelajaran Berorientasi Standar Proses Pendidikan, Kencana, Jakarta.

Selvira, M., (2016), Penerapan Pendekatan Saintifik Pada Siswa Kelas IV di SD Pujokusuman 1 Yogyakarta, Jurnal Pendidikan Guru Sekolah Dasar. 6: 511-517. 
JURNAL PELITA PENDIDIKAN VOL. 6 NO. 1

Halaman : $028-035$

Sudarisman, S., (2015), Memahami Hakikat dan Karakteristik Pembelajaran Biologi dalam Upaya Menjawab Tantangan Abad 21 Serta Optimalisasi Implementasi Kurikulum 2013, Jurnal Florea, 2: 29-35.

Sugiyono, (2015) Metode Penelitian Pendidikan, Alfabeta, Bandung.

Wardani, E.R.S., (2014), Analisis Kesesuaian Kegiatan Pembelajaran Pendekatan Saintifik Dengan Tujuan Pembelajaran di SMAN Mojokerto, Bioedu Berkala Ilmiah Penddikan Biologi, 3: 601-605.

Zaim, M., (2017), Implementing Scientific Approach to Teach English at Senior High School in Indonesia, Asian Social Science, 13: 3340. 